ARQGA/1172

\title{
PREVALENCE OF HEARTBURN AND GASTROESOPHAGEAL REFLUX DISEASE IN THE URBAN BRAZILIAN POPULATION
}

\author{
Joaquim Prado P. MORAES-FILHO, Décio CHINZON, \\ Jaime Natan EISIG, Claudio L. HASHIMOTO and Schlioma ZATERKA
}

ABSTRACT - Background - The epidemiological aspects of heartburn and gastroesophageal reflux disease have been object of growing interest in the last decade because of its increasing prevalence and the complications of the disease. Aims - To evaluate the prevalence of heartburn and gastroesophageal reflux disease as well as their main characteristics in the Brazilian urban population. Methods - A national inquire enrolling 13,959 adults was conducted in 22 Brazilian cities. The inclusion criteria were the presence of heartburn at least once a week ("heartburn group") and age greater than 16 years old. Individuals with heartburn with frequency of more than once a week were considered as having gastroesophageal reflux disease (GERD group). Factors related to the complaint were asked such as predisposing factors, habits (tobacco, alcohol and coffee intake) and body mass index. In this populational study a probabilistic model was used. Results - The results are presented in absolute and relative frequency, which were ponderated estimates of the respective population figures. The global prevalence of heartburn was $11.9 \%$ (1,651 persons). Heartburn once a week was present in 4.6\% (637 persons) and GERD in 7.3\% (1,014 persons). The average ages of both groups were similar (men: $36.9 \pm 15.0$; women: $39.6 \pm 15.1 \mathrm{yrs}$ ). Females were more affected in both groups. The occurrence of GERD increased with age and was more prevalent after 55 years old. The body mass index was in the normal range and similar in both groups (men: $24.7 \pm 4.6$; women: $25.3 \pm 5.2 \mathrm{~kg} / \mathrm{m}^{2}$ ). In both groups the individuals related their symptoms to food intake, fatty and spicy foods (heartburn group: $64.7 \%, 28.5 \%, 17.7 \%$; GERD group: $55.0 \%$, $25.9 \%, 11.7 \%$ respectively). In GERD group, stress $(24.2 \%)$, health problems (22.3\%) were more related to the symptoms than in heartburn group (20.0\% and 15.0\% respectively). Conclusions - The global prevalence of heartburn (11.9\%) is relatively high in the Brazilian urban population, although lower than the reported figure to other countries. Heartburn and GERD have higher prevalence in women and both are related to food intake, fatty and spicy foods; GERD is more prevalent in individuals older than 35 years old.

HEADINGS - Gastroesophageal reflux, epidemiolgy. Heartburn, epidemiology. Prevalence.

\section{INTRODUCTION}

Heartburn is characterized by a discomfort or burning sensation extending from the sternal manubrium to the base of the neck. The duration and frequency of heartburn, even though bad predictors of the severity of esophagitis are strong indicators of the presence of gastroesophageal reflux disease $(\text { GERD })^{(7)}$.

The diagnosis and treatment of GERD are very important because the disease, in addition to the highly disturbing typical symptoms, has a series of known consequences. It may affect the quality of life ${ }^{(21)}$, decrease functional activity ${ }^{(25)}$, increase the health costs ${ }^{(2)}$ and the risk of esophageal carcinoma in the cases of Barrett's esophagus ${ }^{(4)}$.

Despite the increasing importance of the early diagnosis of GERD in clinical, therapeutic and economic terms, there are few studies available on the prevalence of the disease and the profile of these patients ${ }^{(8)}$. Studies have been carried out in different countries with a relatively limited number of subjects ${ }^{(13,15,18,24)}$ or with methodological deficiencies $^{(18)}$. Further, the large scale populational study carried out by Gallup Institute in $1988^{(10)}$ has limitations and did not provide information that might be helpful in establishing the profile of individuals with this disease. Thus, although symptomatic GERD affects a significant part of the population and represents the majority of the carriers of this disease, there are few epidemiological data available. Besides, none of the studies have specifically addressed GERD in a Latin-American context. Mindful of the possible influence of differing demographic, nutritional, socioeconomic and disease factors, the present study was designed.

Department of Gastroenterology, Faculty of Medicine, Clinics Hospital, University of Sao Paulo, Brazil.

Grant support: AstraZeneca - Brazil.

Address for correspondence: Joaquim Prado P. Moraes-Filho - Rua Itapaiuna, 1165 - casa 28 - 05009-001 - São Paulo, SP. E-mail: joaquim.prado@uol.com.br 
The primary objective was to provide a populational appraisal of the prevalence of heartburn and GERD in Brazilian people. The secondary objectives were to evaluate:

1. Symptom and disease distribution according to age groups and gender.

2. Cause of symptom defined by the patient related to food, beverage intake (alcohol and coffee) and smoking habits.

3. Cause of symptom defined by the patient related to emotional aspects (tension, stress, anxiety and sadness).

4. Symptom and body weight ratio assessed by the body mass index (BMI).

\section{MATERIAL AND METHODS}

\section{Subjects}

Samples from the metropolitan areas of 22 highly populated cities in the southern, southeastern, central and northeastern regions of Brazil were chosen to participate in the study, totalizing 32,052,221 inhabitants. For the purpose of the study the sample distribution by age and gender was the same as that of the resident population. A total of 13,959 individuals were interviewed.

Individuals with 16 years of age and over were accepted to participate in the study. First of all, the nature and objective of the questionnaire were explained and after obtaining verbal informed consent, the questions were proposed. In addition to age, the inclusion criteria were positive answer to the presence of at least one weekly episode of retrosternal burning (heartburn).

\section{Staff - Questionnaire}

The team of interviewers were composed by non-health related persons, working for a company specialized in field surveys ("DataFolha" Survey Institute, São Paulo, SP, Brazil), who were especially trained to carry out a populational epidemiological questionnaire to estimate the prevalence of heartburn and GERD and other related information. The interviewers, who did not have access to the study protocol, were totally familiar with the questionnaire and were instructed to better explain any eventual question that might not have been fully understood by the interviewed individuals. The answers obtained in each questionnaire were unknown to other interviewers.

After informing their age and giving voluntary consent to participate in the study, the participants were asked if they ever had a burning sensation in their life, defined as burning feeling starting in the stomach and radiating towards the throat. A positive answer of occasional, sporadic or imprecise occurrence of the symptom excluded individuals from the study. Those with heartburn at least once a week were included in the study. The questionnaire was then continued to obtain additional information.

Individuals with heartburn once a week constituted the "heartburn group". Those who referred the symptom more than once a week were considered as having GERD ("GERD group")(17).
Individuals who gave incomplete or unintelligible answers were excluded from the sample, as well as, those who were not residents, worked for drugstores, pharmaceutical industry or advertisement companies.

The questionnaire included questions related to the following information:

1. Presence and characteristics of heartburn as to location and frequency.

2. Demographic variables: age, gender.

3. Biometry: body mass index: $\mathrm{BMI}=$ weight, $\mathrm{W}(\mathrm{kg}) /$ height, $\mathrm{h}^{2}(\mathrm{~m})$. A BMI of 20 was considered normal; between 20 and 30 overweight; $>30$ obesity ${ }^{(3)}$.

4. Relationship of the symptoms to food (fatty, spicy) and/or beverage intake (alcohol, coffee); anxiety, tension, stress, sadness; "health problems"; cigarette smoking.

\section{Ethics}

The study was approved by the University of São Paulo School of Medicine, São Paulo, SP, Institutional Ethics Review Board.

\section{Statistical Analysis}

In the present populational study a probabilistic model was used. The questionnaires were ponderated according to data of the Brazilian Geography and Statistics Institute (IBGE) by gender and age in all sites where the survey was carried out, ensuring the representativeness of the inclusion and consequent sample.

The questionnaires provided information regarding the rates of individuals with heartburn. Only individuals who met the inclusion criteria were included in the study and answered the full questionnaire. The sample $(13,959)$ may be considered representative of the population since the percentage differences found between the inclusion and the sample profiles are statistically acceptable.

The profiles of individuals with heartburn is shown according to the number of weekly episodes of the symptom in absolute and relative (percentage) values, and are ponderated estimates of the respective populational figures.

Mean and standard deviation of age and BMI variables were calculated to characterize the studied cases.

\section{RESULTS}

A total of 13,959 individuals were interviewed. Considering only those who met the inclusion criteria, the following results were obtained. The global prevalence of heartburn was $11.8 \%$ (1,651 individuals) (heartburn and GERD groups). The prevalence of heartburn group was $4.6 \%$ (637 individuals). The prevalence of GERD group was $7.3 \%$ (1,014 individuals).

The results of demographic data in both groups are shown in Table 1.

The results of the relationship between the groups and age decades are in Table 2.

The results related to the BMI $\left(\mathrm{kg} / \mathrm{m}^{2} \pm \mathrm{SD}\right)$ data are shown in Table 3.

The causes of symptoms as defined by the patients are shown in Tables 4, 5 and Figures 1, 2. 
TABLE 1 - Demographic data

\begin{tabular}{lccc}
\hline & $\begin{array}{c}\text { Heartburn } \\
\text { group }\end{array}$ & GERD group & $\begin{array}{c}\text { Heartburn }+ \\
\text { GERD groups }\end{array}$ \\
\hline $\mathrm{n}$ & $637(38.75 \%)$ & $1,014(61.4 \%)$ & $1,651(100 \%)$ \\
Mean age (years) & $36.9 \pm 15.0$ & $39.6 \pm 15.1$ & $38.2 \pm 15.0$ \\
Mean age - men (years) & $36.3 \pm 15.5$ & $40.7 \pm 15.1$ & $38.5 \pm 15.3$ \\
Mean age - women (years) & $37.2 \pm 15.3$ & $39.1 \pm 15.0$ & $38.1 \pm 15.1$ \\
Men's prevalence & $281(44.1 \%)$ & $349(34.4 \%)$ & $630(38.1 \%)$ \\
Women's prevalence & $356(55.9 \%)$ & $665(65.6 \%)$ & $1,021(61.8 \%)$ \\
\hline
\end{tabular}

TABLE 2 - Heartburn and GERD groups according to age decades

\begin{tabular}{lcc}
\hline Ages (years) & $\begin{array}{c}\text { Heartburn group } \\
(\mathrm{n}=637)\end{array}$ & $\begin{array}{c}\text { GERD group } \\
(\mathrm{n}=1,014)\end{array}$ \\
\hline $16-25 \mathrm{n}(\%)$ & $190(48.6 \%)$ & $201(51.4 \%)$ \\
$26-35 \mathrm{n}(\%)$ & $174(42.9 \%)$ & $231(57.1 \%)$ \\
$36-45 \mathrm{n}(\%)$ & $109(31.0 \%)$ & $242(69.0 \%)$ \\
$46-55 \mathrm{n}(\%)$ & $99(38.7 \%)$ & $157(61.3 \%)$ \\
$>55 \mathrm{n}(\%)$ & $65(26.2 \%)$ & $183(73.8)$ \\
\hline
\end{tabular}

TABLE 3 - BMI $\left(\mathrm{kg} / \mathrm{m}^{2} \pm \mathrm{SD}\right)$

\begin{tabular}{lcc}
\hline & Heartburn group & GERD group \\
\hline Overall BMI & $24.7 \pm 4.6$ & $25.3 \pm 5.2$ \\
Men & $25.0 \pm 3.8$ & $25.3 \pm 4.1$ \\
Women & $24.5 \pm 5.1$ & $25.4 \pm 5.7$ \\
\hline
\end{tabular}

TABLE 4 - Causes of symptoms as defined by the patients. Relationship with food, beverage and tabagism

\begin{tabular}{lcc}
\hline & $\begin{array}{c}\text { Heartburn Group } \\
(\mathrm{n}=637)\end{array}$ & $\begin{array}{c}\text { Gerd Group } \\
(\mathrm{n}=1,014)\end{array}$ \\
\hline Food Intake (n) & $412(64.6 \%)$ & $558(55.0 \%)$ \\
Men & $178(43.2 \%)$ & $196(35.1 \%)$ \\
Women & $234(56.7 \%)$ & $362(64.8 \%)$ \\
Fatty foods (n) & $182(28.5 \%)$ & $263(25.9 \%)$ \\
Men & $79(43.4 \%)$ & $77(29.2 \%)$ \\
Women & $103(56.5 \%)$ & $186(70.7 \%)$ \\
Spicy foods (n) & $113(17.7 \%)$ & $119(11.7 \%)$ \\
Men & $55(48.6 \%)$ & $41(34.4 \%)$ \\
Women & $58(51.3 \%)$ & $78(65.5 \%)$ \\
Alcohol (n) & $76(11.9 \%)$ & $88(8.6 \%)$ \\
Men & $53(67.0 \%)$ & $64(72.7 \%)$ \\
Women & $23(29.1 \%)$ & $24(27.2 \%)$ \\
Coffee (n) & $59(9.2 \%)$ & $97(9.5 \%)$ \\
Men & $27(45.7 \%)$ & $37(38.1 \%)$ \\
Women & $32(54.2 \%)$ & $60(61.8 \%)$ \\
Tabagism (n) & $39(6.1 \%)$ & $84(8.2 \%)$ \\
Men & $25(64.1 \%)$ & $49(58.3 \%)$ \\
Women & $14(35.8 \%)$ & $35(41.6 \%)$ \\
\hline
\end{tabular}

TABLE 5 - Causes of symptom defined by the patients: stress, health problems

\begin{tabular}{lcc}
\hline & $\begin{array}{c}\text { Heartburn group } \\
(\mathrm{n}=637)\end{array}$ & $\begin{array}{c}\text { GERD group } \\
(\mathrm{n}=1014)\end{array}$ \\
\hline Anxiety, tension, stress, sadness (n) & $127(19.9 \%)$ & $245(24.1 \%)$ \\
$\quad$ Men & $44(34.6 \%)$ & $62(25.3 \%)$ \\
Women & $83(65.3 \%)$ & $183(74.6 \%)$ \\
Health problems (n) & $96(15.0 \%)$ & $226(22.2 \%)$ \\
$\quad$ Men & $32(33.3 \%)$ & $71(31.4 \%)$ \\
$\quad$ Women & $64(66.6 \%)$ & $155(68.5 \%)$ \\
\hline
\end{tabular}

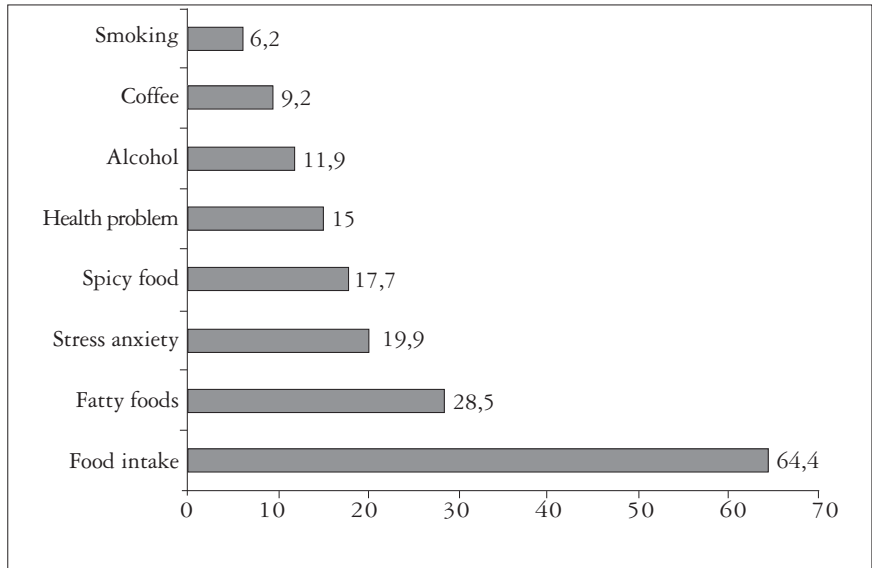

FIGURE 1. Heartburn group. Cause of symptoms

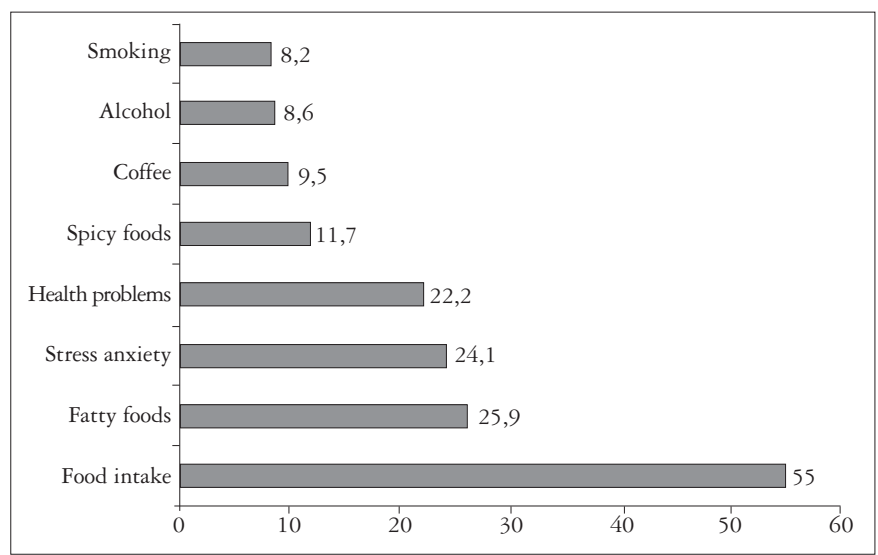

FIGURE 2. GERD group. Cause of symptons.

\section{DISCUSSION}

Brazil has a population of $169,799,170^{(12)}$ with an urban population of $137,961,820$ millions. The 22 more densely populated cities (corresponding to 32,052,112 inhabitants) were considered in the present study. A sample of 13,959 persons was taken for interviews.

The ethnic distribution of the population is diverse and varies from one to other region. Considering the nation as a whole, Caucasians represent 53.8\%, Afro-Brazilians 6.2\%, mulattos $39.1 \%$, Asians $0.5 \%$, others $0.4 \%^{(12)}$. However these figures should be carefully analyzed due to the heterogeneous regional distribution: in the southern region, for example, where the European migration, especially German and Italian, was very intense, Caucasians clearly prevail. Since it is difficult in a survey like the present to obtain accurate information regarding race or ethnic background, this question was not included in the questionnaire. Even so it may be concluded that eventual prevalence of one or another group in the different regions were diluted in the large number of individuals interviewed in the sample. On the other hand, the interest in populational studies lays exactly on the fact that 
the results provide estimates and allow us to make inferences for the population as a whole ${ }^{(1)}$.

The major objectives of the present study were to establish the prevalence and characteristics of heartburn, which may, depending on the frequency and duration, strongly suggest a diagnosis of GERD. Since heartburn is, by definition, a retrosternal burning sensation, we initially tried to carefully establish the location defined by participants.

The definition of GERD is not uniformly accepted and several definitions have been proposed ${ }^{(7,17,26)}$, all of them assuming that patients who complain of heartburn, regardless of the presence of injured esophageal mucosa, have GERD ${ }^{(9)}$, which is not always true. When does heartburn really indicate the presence of GERD? In the present casuistic individuals who complained of heartburn at least twice a week were considered as having GERD. Although this criterion is somehow uncertain ${ }^{(8)}$, we assumed that the presence of heartburn 2 or more times a week is highly suggestive of the presence of GERD ${ }^{(17)}$.

Quantitative questions were avoided in the questionnaire, especially those related to a more distant past, e.g., the duration of the symptom or, more precisely, the time of history. Although this question might have provided interesting information, it was not included because it could pose problems with the study design such as the fortuitous lack of accuracy of the answers and selection bias.

Studies on the prevalence of GERD are relatively limited. NEBEL et al. ${ }^{(20)}$ studied 1,004 outpatients who were part of the staff of a hospital in the United States and found 11\% had heartburn daily and $12 \%$ with weekly symptoms. The sample, however, was not representative of the population as a whole and in addition, the investigation was not totally validated ${ }^{(20)}$. Another frequently cited study was carried out by Gallup Institute in the United States in $1988^{(10)}$. The results showed that $44 \%$ of the population complained of heartburn at least once a month. However these data should be carefully considered, since the methodology used to obtain the information has not been reported and the results have not been published in a peer-reviewed medical journal ${ }^{(10)}$. More recently, LOCKE et al. ${ }^{(15)}$ reported a stratified sample in a small community in the United States, using a validated questionnaire to survey GERD. Letters were sent to 2,200 residents and 2,073 answered the questionnaire. Results show that $19.8 \%$ had heartburn once a week and $60 \%$ had occasional symptoms ${ }^{(15)}$. Similar data have been reported in other developed countries ${ }^{(13,24)}$. These studies, although methodologically consistent, were not representative in populational terms.

Epidemiological information on the occurrence of heartburn in developing countries are even more scarce, and it is unknown if the figures are similar to those above. In our casuistic, the global prevalence of heartburn was $11.9 \%$, the prevalence of heartburn occurring only once a week was $4.6 \%$ and the prevalence of GERD (heartburn more than once a week) was $7.3 \%$. The present study population showed lower prevalence of heartburn and GERD than others studies ${ }^{(15,24)}$, but our inclusion criteria of heartburn (once a week) and
GERD (more than once a week) was more restrictive and may have omitted cases that otherwise would have been included. On the other hand, atypical manifestations such as cough, hoarseness, asthma, were not taken into consideration and may also represent a significant figure. We may then suppose that the actual prevalence of GERD should be higher than the reported in the present series.

The prevalence of women in $55.9 \%$ of the cases of GERD is noteworthy, although similar findings have been reported by LIND et al. ${ }^{(14)}$ who found $58 \%$ of women in a study carried out in 25 Danish and Swedish centers including 424 patients with heartburn associated to GERD. CARLSSON et al. ${ }^{(5)}$ compared the clinical characteristics of patients with symptomatic GERD to patients with erosive esophagitis. In the first group, $62 \%$ were women and in the second group, $42 \%$ were women. These results, combined to those obtained in the present study suggest that symptomatic GERD is definitely more prevalent in women.

According to our data the occurrence of GERD increased with age, and is more prevalent after 55 years old. This observation is in accordance with other authors ${ }^{(22)}$, which was actually expected since aging decreases the motor power of the esophagus, which was named "presbyesophagus" by HOLLIS and CASTELL ${ }^{(11)}$. It is well known that altered motility in the esophagus in older individuals favor the development of gastroesophageal reflux ${ }^{(11)}$.

A lot of cases of heartburn once a week were observed in individuals with less than 35 years old. It is difficult to interpret this finding, but it may be related to the presence of functional complains affecting more frequently young people ${ }^{(11)}$.

The information about body weight and height were obtained through the questionnaire and as such should be considered with restrictions. Even so the BMI was within the normal range for both genders and for individuals with heartburn group and in GERD group. This finding suggests that the presence of the symptom, regardless of the frequency, is not related to body weight or might be related to the apparent limited cases of obesity in the Brazilian population ${ }^{(6)}$.

The perception of the participants regarding their complaint and worsening factors were interesting: most of people in both genders related the presence of the symptom to food ingestion. In this case, fatty foods prevailed, especially in women. This finding was expected since it is known that fat relaxes the lower esophageal sphincter ${ }^{(18,19)}$ and slows gastric emptying ${ }^{(16)}$ which are related to gastroesophageal reflux.

The item "anxiety, tension, stress, sadness" tried to assess the relation of the symptom with emotional discomfort. This relation was observed in $19.9 \%$ and $24.1 \%$ of the individuals in the heartburn group and those of the GERD group, respectively, once again with a marked prevalence of women. The relation of emotional status with the presence of symptom might in fact only be coincidental, but it might also be that stressed, anxious, depressed individuals, who have a greater perception of their visceral symptoms, complained of the symptom more often. It should be further investigated if the emotional status in fact triggers or has an actual correlation with heartburn and GERD. 


\section{CONCLUSIONS}

In the studied urban Brazilian population:

1. The global prevalence of heartburn at least once a week was $11.9 \%$. Heartburn present only once a week had a prevalence of $4.5 \%$. The prevalence of GERD was $7.3 \%$.

2. Heartburn present once a week was apparently more common in individuals with less than 35 years old. The occurrence of GERD increased with age and was more prevalent after 55 years old. In both cases, the prevalence was greater in women.

3. Ingestion of foods was considered an important factor by the individuals with heartburn once a week (64.6\%) and with GERD (55.0\%), especially in women. Fatty foods were considered the most relevant worsening factor for heartburn group (28.5\%) and for GERD group (25.9\%).

4. "Tension, stress, anxiety, sadness" was the second most important factor in those with heartburn once a week (19.9\%) and GERD (24.1\%), with higher prevalence in women. Other causes of symptoms ("health problems", tabagism) were less indicated by heartburn group and GERD group.

5. BMI was within the normal range in both groups and sexes.

\section{ACKNOWLEDGEMENTS}

Prof. Eamon Quigley and Prof. Henry Cohen for the suggestions to the manuscript.

Moraes-Filho JPP, Chinzon D, Eisig JN, Hashimoto CL, Zaterka S. Prevalência da pirose e da doença gastroesofágica numa população urbana brasileira. Arq Gastroenterol 2004; 42(2):122-7.

RESUMO - Racional - Os aspectos epidemiológicos da azia e da doença do refluxo gastroesofágico tem sido objeto de interesse crescente na última década devido o aumento na prevalência e nas complicações da doença. Objetivos - Avaliar a prevalência da doença do refluxo gastroesofágico e da azia e as principais características da doença na população urbana do Brasil. Métodos - Inquérito nacional avaliou 13.959 indivíduos em 22 cidades brasileiras. Os critérios de inclusão foram:presença de azia, pelo menos, uma vez na semana e idade maior de 16 anos (grupo azia); presença de azia com freqüência maior que uma vez na semana, considerado como portadores da doença do refluxo gastroesofágico (grupo DRGE). Os fatores relacionados às queixas foram questionados como: fatores precipitantes; hábitos (tabaco, álcool e consumo de café); índice de massa corporal . Neste estudo populacional foi usado modelo probabilístico na analise estatística. Resultados - Foram apresentados em freqüência relativa e absoluta, que era a estimativa ponderada da respectiva população. A prevalência global da azia foi de 11,9\% (1.651 indivíduos). Azia uma vez por semana esteve presente em 4,6\% (637 indivíduos) e doença do refluxo gastroesofágico em 7,7\% (1.014 indivíduos). A idade média foi semelhante em ambos os grupos (homens: 36,9 $\pm 15,0$; mulheres: 39,6 $\pm 15,1$ anos). As mulheres foram mais afetadas em ambos os grupos. A ocorrência de doença do refluxo gastroesofágico aumentou com a idade e foi mais prevalente após os 55 anos de idade. $O$ índice de massa corporal esteve na faixa normal e foi similar em ambos os grupos (homens: $24,7 \pm 4,6$; mulheres: $25,3 \pm 5,2 \mathrm{~kg} / \mathrm{m}^{2}$ ). Em ambos os grupos os indivíduos relataram seus sintomas à ingestão de comida, gorduras e alimentos picantes (grupo azia: 64,7\%, 28,5\%, 17,7\%; grupo DRGE: 55,0\%, 25,9\%, 11,7\%, respectivamente). No grupo DRGE, estresse (24,2\%) e problemas de saúde (22,3\%) foram os sintomas mais relatados que no grupo azia (20,0\% e 15,0\%, respectivamente). Conclusões - A prevalência global de azia (11,9\%) é relativamente elevada na população urbana brasileira, apesar de mais baixa em comparação a outros paises. Azia e doença do refluxo gastroesofágico têm maior prevalência em mulheres e ambos são relacionados à ingestão de alimentos, alimentos gordurosos e picantes. A doença do refluxo gastroesofágico é mais freqüente em indivíduos maiores que 35 anos.

DESCRITORES - Refluxo gastroesofágico, epidemiologia. Pirose, epidemiologia. Prevalência.

\section{REFERENCES}

1. Andrade ALSS, Zicker F. Estudos de prevalência. In: Andrade ALSS, Zicker F, editores. Métodos de investigação epidemiológica em doenças transmissíveis. Brasília: Organização Pan-Americana de Saúde. Fundação Nacional de Saúde; 1997, v.1, p.33-42

2. Bloom BS, Jayadevappa R, Wahl P, Cacciamanni J. Time trends in cost of caring for people with gastroesophageal reflux disease. Am J Gastroenterol 2001;96(Suppl):S64-9.

3. Bray GA. Overweight is risking fate. In: Wurtman RJ, Wurtman JJ, editors. Human obesity. New York: The New York Academy of Sciences; 1987. p.14-28.

4. Cameron AJ. Epidemiology of columnar lined esophagus and adenocarcinoma. Gastroenterol Clin North Am 1997;26:487-94.

5. Carlsson R, Dent J, Watts R. Gastro-oesophageal reflux disease in primary care: an international study of different treatment strategies with omeprazole. Eur J Gastroenterol Hepatol 1998;10:119-24

6. Chacra AR. Obesidade. In: Borges DR, Rothschild HA, editores. Atualização terapêtica 2003. $21^{a}$ ed. São Paulo: Artes Médicas; 2003: p.407-8.
7. Dent J, Brun J, Fendrick AM, Fennerty MB, Janssens J, Kahrilas PJ, Lauritsen K, Reynolds JC, Shaw M, Talley NJ. An evidence based appraisal of reflux disease management. The Genval Workshop Report. Gut 1999;44 (Suppl):S1-16.

8. Eisen G. The epidemiology of gastroesophageal reflux disease: what we know and what we need to know. Am J Gastroenterol 2001;96(Suppl):S16-8.

9. Fass R. Focused clinical review; non-erosive reflux disease. Medscape Gastroenterol 2001;3:1-15.

10. Gallup Organization National Survey. Heartburn across America. Princeton, NJ: The Gallup Organization; 1988.

11. Hollis JB, Castell DO. Esophageal function in elderly man. A new look at "presbyesophagus". Ann Intern Med 1974;80:371-4.

12. Instituto Brasileiro de Geografia e Estatística. Censo demográfico 2000 características da população dos domićlios: resultados do universo. Rio de Janeiro; c2001. p.127.

13. Jones RH, Lydeard SE, Hobbs FD. Dyspepsia in England and Scotland. Gut 1990;31:401-5. 
14. Lind T, Havelund T, Lundell L, Glise H, Lauritsen K, Pedersen SA, Anker-Hansen O, Stubberod A, Eriksson G, Carlsson R, Junghard O. On demand therapy with omeprazole for the long-term management of patients with heartburn without oesophagitis-a placebo-controlled randomized trial. Aliment Pharmacol Ther 1999;13:907-14.

15. Locke GR, Talley NJ, Fett SL, Zinsmeister AR, Melton LJ. Prevalence and clinica spectrum of gastroesophageal reflux: a population based study in Olmsted County, Minnesota. Gastroenterology 1997;112:1448-56.

16. McCallum RW, Berkowitz DM, Kerner E. Gastric emptying in patients with gastroesophageal reflux. Gastroenterology 1981;80:285-91

17. Moraes-Filho JPP, Cecconello I, Gama-Rodrigues J, Castro LP, Henry MA, Meneghelli UG, Quigley E. Brazilian Consensus on Gastroesophageal Reflux Disease: proposals for assessment, classification, and management. Am J Gastroenterol 2002;97:241-8.

18. Nebel OT, Castell DO. Lower esophageal sphincter pressure changes after food ingestion. Gastroenterology 1972; 63:778-83.

19. Nebel OT, Castell DO. Inhibition of the lower oesophageal sphincter by fat - a mechanism for fatty food intolerance. Gut 1973;14:270-4.

20. Nebel OT, Formes MF, Castell DO. Symptomatic gastroesophageal reflux: incidence and precipiting factors. Dig Dis Sci 1976;21:953-6.
21. Revicki DA, Wood M, Maton PN, Sorensen S. The impact of gastroesophageal reflux disease on health-related quality of life. Am J Med 1998.104:252-8.

22. Sonnenberg A, El-Serag HB. Clinical epidemiology and natural history of gastroesophageal reflux disease. Yale J Biol Med 1999;72:81-92.

23. Talley NJ, Stanghellini V Heading RC. Functional gastroduodenal disorders. In Drossman DA, Corrazziari E, Talley NJ Thompson G, Whitehead WE, editors. Rome II: the functional gastrointestinal disorders: diagnosis, pathophysiology, and treatment: a multinational consensus. $2^{\text {nd }}$ ed. McLean, VA: Degnon; c2000.

24. Thompson WG, Heaton KW. Heartburn and globus in apparently healthy people. J Can Med Assoc 1982;126:46-8.

25. Wahlqvist P. Symptoms of gastroesophageal reflux disease, perceived productivity and health related quality of life. Am J Gastroenterol 2001;96 (Suppl):S57-61.

26. Waring JP. Non erosive reflux disease. Semin Gastrointest Dis 2001;12:33-7 